\title{
Factors Influencing Customer Engagement in Mobile Applications
}

\author{
Aiste Dovaliene, Zaneta Piligrimiene, Akvile Masiulyte
}

\author{
Kaunas University of Technology \\ Gedimino st. 50, LT-44239, Kaunas, Lithuania \\ E-mail.aiste.dovaliene@ktu.lt, zaneta.piligrimiene@ktu.lt,akvile.masiulyte@gmail.com
}

cross $^{\text {ref }}$ http://dx.doi.org/10.5755/j01.ee.27.2.14030

\begin{abstract}
Ability to engage customers is crucial for highly competitive market of mobile applications. Notwithstanding, there is no consensus in scientific literature regarding the determinants of customer engagement in mobile applications. Thus, the aim of this research is to reveal factors driving customer engagement in mobile applications. Theoretical studies on customer engagement in mobile applications and its characteristics are based on comparative and systematic analysis of scientific literature. Empirical research is performed by applying quantitative research - survey. Results of empirical research confirm all three customer engagement dimensions in using mobile applications: emotional, cognitive, and behavioural. Results of regression analysis reveal that customer sociability and technical convenience are the most important factors when considering customer engagement in mobile applications, while customer satisfaction and hedonic factors were insignificant. The manuscript provides some useful practical implications for developers how to increase customer engagement in mobile applications.
\end{abstract}

Keywords: Customer Engagement, Mobile Applications, Engagement Dimensions, Sociability, Technical Convenience, Customer Satisfaction, Hedonism.

\section{Introduction}

According to statistics presented by Euro monitor International (2016), the possession of smartphones is impressively growing in the most of the countries, e.g. from 14.5 percent in 2010 to 58 percent in 2015 in Lithuania; 13.2 and 55.2 percent respectively in Eastern Europe; 18.5 and 65.7 percent respectively in Western Europe. The growth of possession of smartphones and other mobile devices, and mobile applications (apps) along with them changes consumer behaviour and requires adequate decisions to be taken in order to fulfil their expectations. Kim, Wang and Malthouse (2015) argue that "with the explosive growth of mobile technologies and app culture, customers' expectations of a useful and enjoyable mobile experience will become the norm" (p. 39).

However, in the context of fast growing number of mobile apps it is determined that even $2 / 3$ of apps have never been downloaded (Lim et al., 2015). In addition, Sterling (2014) argues that customers devote their time only for few of all 24 apps used per month by particular user (the research was carried out with the US and the UK users). Moreover, the results of extended worldwide study $(10,208$ users from more than 15 countries) presented by Lim et al. (2015) shows that app user behaviour differs significantly across countries.

The customer engagement concept is among the first on the list of research priorities announced by Marketing Science Institute for 2014-2016 years (MSI, 2015a), i.e. in the group of research priorities dedicated to understanding customers and customer experience. Moreover, 'leveraging digital/social/mobile technology' is the fifth research priority announced by the same institute (MSI, 2015b). The importance of research on customer engagement is acknowledged by scholars and practitioners in various fields. Taking the growth of mobile devices and inadequate use of mobile apps into account it could be stated that knowing how to engage customers is the main precondition for success in today's highly competitive market of mobile applications seeking to retain customer.

In their research on customer engagement Kim et al. (2015) confirm the usefulness of it arguing that the more a customer is engaged in the app the more money he is willing to spend. Moreover, those customers who are engaged in branded app will strengthen their relationships with the brand (Kim, et al. 2015). The importance of customer engagement for company performance was pointed out by various researchers from different countries (see for e.g., Van Doorn et al., 2010; Kumar et al., 2010; Brodie, Hollebeek, Juric, \& Ilic, 2011; Vivek, Beatty, \& Morgan, 2012; Breidbach, Brodie \& Hollebeek, 2014; Kim et al., 2015; Dovaliene, Masiulyte, \& Piligrimiene, 2015; etc.). Van Doorn et al. (2010) suggest customer engagement behavior as a basis for differentiating customers when pursuing long-term customer relationship with them. In most cases customer engagement is being treated as an antecedent of customer perceived value, satisfaction and loyalty (e.g., Mollen and Wilson (2010), Brodie, Ilic, Juric, and Hollebeek (2013)), meanwhile Kim, Kim and Wachter (2013a) argue that satisfaction with services is a precondition of customer engagement behaviour. Factors influencing customer engagement were analysed by Banyte, Tarute, and Taujanskyte (2014) in the context of health care services; Kim et al. (2013a) - mobile environment; Mollen and Wilson (2010), Fernandes and Remelhe (2015) - online activities; Krishna, Lazarus, and Dhaka (2013) - consumer durables and automobile industry; Hollebeek, Glynn, and Brodie (2014) - social media, etc.

Despite the considerable growing interest in customer engagement, there is still lack of agreement between scholars 
regarding this phenomenon, its conceptualization and the impact it has on its consequences. There is no evidence of what drives customer engagement in mobile applications, especially considering country specific differences when analysing behaviour of mobile applications users. Thus, this research seeks to contribute to the current body of knowledge by answering the following question: What are the drivers of customer engagement in mobile applications?

The aim of this research is to reveal factors influencing customer engagement in mobile applications.

Methods: theoretical studies on customer engagement and factors influencing it were based on comparative and systematic analysis of scientific literature, while empirical research was performed by applying quantitative research - survey, limited to the territory of Lithuania.

\section{Theoretical Background}

Customer engagement. Different conceptualizations of customer engagement and its construct exist in scientific literature. There were several attempts to look at the engagement from the holistic perspective. Breidbach et al. (2014) introduced the concept of engagement ecosystem, which includes all related actors and their relations and explains the role of individual engagement platforms in the process of exchange and integration of the resources of all parts. The similar kind of approach was employed in the conceptual framework of customer engagement ecosystem proposed by Maslowska, Malthouse and Collinger (2016). They argue that there should be excluded "four components of customer engagement: customer brand experience, brand dialogue behaviours, brand consumption and shopping behaviours" (Maslowska et al., 2016, p. 478). Additionally, they point out that there are other two factors witch interrelate with each other and with all four before mentioned factors, i.e. the brand itself and such actors as other consumers and the media (Maslowska et al., 2016). Despite the promising future of such kind of approach it still lacks empirical justification. Moreover, the employment of those ecosystems requires massive amount of various multilevel data (known as big data) that is difficult to process.

In this article customer engagement is considered from the customer related perspective, i.e. at micro level of analysis. In such a case, the main actor or subject of the engagement usually is a customer, while the object of it may vary depending on the context of the research, and could be brand (in virtual or physical environment), service product, mobile application, game, studies at university, etc. The variety of customer engagement situations leads to different ways of its conceptualisation. The variety of the definitions of customer engagement reflects, according to Hollebeek (2013, p. 18), "the lack of consensus pertaining to the specific definition of focal engagement-based concepts" Higgins and Scholer (2009) refer to psychological side of engagement as "a state of being involved, occupied, fully absorbed, or engrossed in something..." (Higgins \& Scholer, 2009, p. 102). The similar definition is proposed by Brodie et al. (2011, p. 9), treating customer engagement as a psychological state that occurs by virtue of interactive, cocreative customer experiences with a focal agent/object (e.g., a brand) in focal service relationships". Meanwhile
Mollen and Wilson (2010) reveal the multidimensional nature of customer engagement, treating it as "customer's cognitive and affective commitment to an active relationship with the brand..." (Mollen \& Wilson, 2010, p. 923). Vivek et al. (2012, p. 127) define customer engagement as "the intensity of an individual's participation in and connection with an organization's offerings and/or organizational activities, which either the customer or the organization initiate". The latter definition points out the behavioural nature of customer engagement phenomenon and could be related to the understanding of value co-creation evolved along with the concept of Service-dominant logic. Despite the lack of consensus regarding the conceptualization of customer engagement we do not seek to provide another definition of the phenomenon, as it is context specific one and we believe that the content of it could be better described by its dimensions.

The multidimensionality of customer engagement was confirmed by various studies (see, e.g., Brodie et al., 2011; Dessart, Veloutsou, and Morgan-Thomas, 2016). In their thorough research on "consumer engagement studies in marketing" Dessart et al. (2016) show that customer engagement has been analysed employing different approaches to its content. Some researchers identify one dimension, in most cases either emotional, either behavioural, sometimes motivational dimension. However, studies incorporating multidimensional approach dominate in nowadays scientific literature, by identifying behavioural, affective/ emotional and cognitive dimensions (see, Brodie et al., 2011; Dessart et al., 2016). In some cases social (Vivek et al., 2012) dimension has been added. The literature analysis confirms that "to date, there is no agreement on the best way to represent engagement, nor is there consensus on the meaning of the dimensions" (Dessart et al., 2016, p. 402). The latter authors tried to fill this gap of knowledge by identifying 3 dimensions and 7 sub-dimensions of customer engagement: affective (enthusiasm, enjoyment); behavioural (sharing, learning, and endorsing); and cognitive (attention, absorption).

Relying on the recent trends in marketing literature and on the results of our previous research (see Dovaliene et al., 2015), customer engagement in mobile applications is being treated as a multidimensional construct. According to the suggestions made by Macey and Schneider (2008), and Brodie et al. (2011; 2013), three customer engagement dimensions are identified: cognitive, emotional, and behavioural. This is closely related to cognitive, affective and conative stages of mobile user engagement, proposed by Kim et al. (2013a). Depending on the expression of the identified dimensions, different levels of customer engagement could be determined, followed by diverse consequences. In accordance with Bellman et al. (2011), mobile phone apps affect brand attitude as well as the willingness to purchase the brand. And in contrary, as assumed by Kim et al. (2015), a branded app that does not fulfil consumers' expectations will lead "to negative brand attitudes, which will result in a decrease in purchase intention or actual purchase behaviour" (Kim et al., 2015, p.31). Thus, "understanding how to maximize the impact of mobile phone apps will be a key topic for future research" (Bellman et al., 2014, p. 191). Consequently, the main task of marketers and apps developers is to find out factors driving customer engagement in mobile apps. 
Factors of customer engagement. According to Zhao and Balague (2015), one of the main challenges companies face in mobile environment is to find out how to acquire and retain customer attention as mobile devices are often used in noisy and disturbing environment. In such circumstances to achieve customer engagement is a kind of difficult task. However, younger users of mobile devises may demonstrate behavioural engagement even in the most uncomfortable situations. Thus, in accordance with various research (e.g., Van Doorn, et al., 2010; Gambetti, \& Graffigna, 2010), it could be stated that individual customer characteristics and company efforts may both lead to different levels of customer engagement.

Bellman et al. (2011) analyse branded apps and indicate two categories of those apps: informational and experiential. Informational app content, referring to Kim, Lin, Sung (2013b), provides utilitarian or functional experiences, letting consumers to achieve their goals more easily (for example, to save money, to pay for services, get coupons, etc.). In contrast, "experiential content offers experiential-based incentives (e.g., games, chat rooms), provides intrinsic enjoyment and entertainment" (Kim et al., 2013b, p. 56). Ho and Syu (2010) support the latter statement by arguing that the main motive to engage in mobile application is "relaxing and relieving stress". It was suggested that "hedonic properties can themselves contribute to engagement strength" (Higgins \& Scholer, 2009), i.e. a customer may in advance anticipate pleasure from particular activity, and those expectations may lead to a greater engagement.

Utilitarian and experience-based motives correlate to functional and hedonic kind of motivations, identified by Kim et al. (2013a). Functional motivation is treated as efficiency, ease of use, saving time, while hedonic - as fun, enjoyment, and pleasure. In addition, authors indicate third motive of mobile user engagement - social, i.e. desire to connect and share with others (Kim et al., 2013a).

Real-time context specific information, including recommendations, leads to "new consumer behaviours in the market" (Zhao \& Balague, 2015).

According to Zhang et al. (2014), customer sociability occurs through mutual interactions in social/ mobile environments, which could be treated as a platform for customers with similar interests, where they may recommend and comment on various services. "During interactions, customers build their online identities and form networks to obtain social benefits, such as social support, friendship and intimacy" (Zhang et al., 2014, p. 1020). According to them, the support from others is one of the major social values gained through the interactions, because then customer feels himself being cared and valued by others. Sociability also refers to participation, which is related to the extent to which customers provide constructive feedback and helpful suggestions on the service (Leckie, Nyadzayo, \& Johnson, 2016).

Various researchers propose satisfaction as a consequence of customer engagement, however several research have proved it as an antecedent of customer engagement behaviour (e.g. Van Doorn et al., 2010, Kim et al., 2013a). However, its role could be twofold: it may act as an antecedent of customer engagement for existing customers, on the contrary - it could be treated as a consequence for new customers (Brodie et al., 2011). According to Sashi (2012, p. 262), "satisfaction is a necessary condition for customer engagement. But it is not sufficient for customer engagement". In the context of relational orientation the satisfaction should be considered as an overall evaluation, not as a transaction related factor, as "overall satisfaction is based on information from all previous experiences with the service provider" (Jones \& Suh (2000, p. 48). Thus, to determine the role of customer satisfaction in the case of customer engagement in mobile applications, customer satisfaction is being treated as an overall customer satisfaction taking in mind all previous transactions, because customer cannot exclude previous experience when evaluating current one. Customer overall satisfaction has been proved as adequate measure of customer satisfaction by various previous research (Spiteri \& Dion, 2004; Jones \& Suh, 2000).

Referring to performed literature analysis, factors of customer engagement in mobile applications are grouped into three groups, similar to suggestions of Kim et al. (2013a), adding customer overall satisfaction as a separate factor:

- Technical convenience (Quality of provided information (Mollen \& Wilson, 2010); Interactivity of virtual environment (Mollen \& Wilson, 2010; Zhang et al., 2014); Design and functionality (Kim et al., 2013a); Communication of company (Kim et al., 2013b); Practical side of problem solving (Higgins \& Scholer, 2009; Kim et al., 2013a));

- Hedonism (Experienced pleasure (Kim et al., 2013b; Kim et al., 2013a; Mollen \& Wilson, 2010); Relaxing (Ho \& Syu, 2010); Feeling of winner (Krishna et al., 2013));

- Customer sociability (Social interactivity; Personal integrity and personal identity (Zhang et al., 2014); Social skills (Zhang et al., 2014; Hollebeek et al., 2014; Kim et al., 2013a); The need of feedback (Krishna et al., 2013); Personal competencies (Banyte et al., 2014));

- Customer overall satisfaction (Sashi, 2012; Higgins \& Scholer, 2009; Jones \& Suh, 2000).

\section{Research Design}

The aim of the research was to explore the effect of the identified factors, namely, hedonism, customer sociability, technical convenience and overall satisfaction with apps, on customer engagement in mobile applications. In particular, the authors wanted to reveal if and how those factors impact overall customer engagement and engagement as described via three dimensions: cognitive, emotional and behavioral (see Figure 1). 


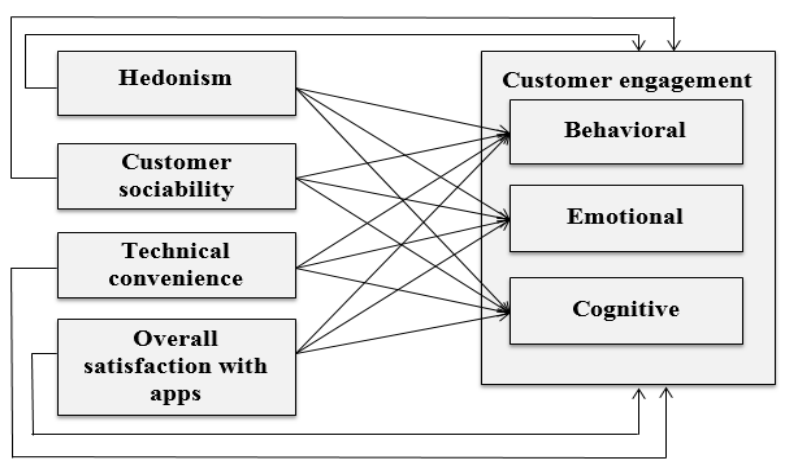

Figure 1. Research model

As the aim of the research shows the intention to test the relations among the constructs in the model, it calls for a quantitative research approach. The online survey method was chosen for the data collection. Online survey brings the challenge for selecting target respondents and forces to rely on nonprobability sampling. Anyway, such techniques as sending invitations to participate in the survey via emails, Facebook to persons receptive to new technologies and mobile apps users hopefully enabled to reach the target population. 196 respondents with valid questionnaires were reached. The females were dominant in the sample (64\% females and $36 \%$ males). The majority $(50 \%)$ of all the respondents belonged to the age group of 19-24 years, $26 \%$ of respondents were younger than 18 years old and the remaining $24 \%$ were older than 25 years, the oldest being 56 years old.

The research instrument consisted of two main parts. The first one was dedicated to reveal the general demographic related information about mobile apps users in Lithuania. The second part involved questions for measuring the factors that possibly drive customer engagement and questions for customer engagement itself. The scales were constructed as follows:

- A scale for measuring hedonism as one of customer engagement drivers was adapted from Kim et al. (2013a) and consisted of 3 items.

- Customer sociability scale was developed according to Zhang et al. (2014) and Kim et al. (2013a) with 5 items.

- The scale for measurement of technical convenience consisted of 4 items developed according to the insights of Mollen \& Wilson (2010) and Kim et al. (2013a).

- Customer satisfaction was measured with a single item adapted from Kim et al. (2013a), representing the overall satisfaction with use of mobile apps.

- A scale confirmed by Cheung et al. (2011) was adapted for customer engagement with mobile apps measurement, using for this purpose 11 items (behavioural dimension - 4 items, emotional dimension -4 items and cognitive dimension -3 items).

All items were measured on 5 point Likert scales, with 1 - "completely disagree" and 5 - "completely agree". The reliability of scales was tested with Cronbach alpha that confirmed internal consistency of scales with the coefficients ranging from 0.698 to 0.814 (Table 1 ).
The reliability of measurement scales

\begin{tabular}{l|c|c}
\hline Scale & $\begin{array}{c}\text { No. of items in } \\
\text { a scale }\end{array}$ & $\begin{array}{c}\text { Cronbach alpha } \\
\text { coefficient }\end{array}$ \\
\hline Hedonism & 3 & 0.602 \\
\hline Customer sociability & 5 & 0.814 \\
\hline Technical convenience & 4 & 0.717 \\
\hline $\begin{array}{l}\text { Overall satisfaction } \\
\text { with apps }\end{array}$ & 1 & - \\
\hline Cognitive engagement & 3 & 0.703 \\
\hline Emotional engagement & 4 & 0.698 \\
\hline $\begin{array}{l}\text { Behavioural } \\
\text { engagement }\end{array}$ & 4 & 0.715 \\
\hline $\begin{array}{l}\text { Overall customer } \\
\text { engagement }\end{array}$ & 11 & 0.811 \\
\hline
\end{tabular}

Statistical data analysis was performed with the data processing software SPSS version 23 including descriptive statistics, correlation and regression analysis methods.

\section{Research Results}

The findings are presented in the following order: first, the results of descriptive statistics are provided, and then the results of correlation and regression analysis are presented.

Table 2 shows the means and standard deviations of the main research variables, i.e., drivers for consumer engagement and consumer engagement itself as expressed via three dimensions. Overall satisfaction with apps has the highest mean rating (3.83) as well as hedonism (3.75). Respondents also expressed recognition of technical convenience that mobile apps provide (3.47). However, the ratings of sociability were the lowest (2.74), indicating that this aspect was not considered by respondents as dominant in using mobile apps.

Table 2

\section{Mean scores of the main constructs}

\begin{tabular}{l|c|c}
\hline \multicolumn{1}{c|}{ Construct } & Mean & SD \\
\hline Hedonism & 3.75 & 0.628 \\
\hline Customer sociability & 2.74 & 0.882 \\
\hline Technical convenience & 3.47 & 0.697 \\
\hline Overall satisfaction with apps & 3.83 & 0.785 \\
\hline Cognitive engagement & 3.49 & 0.856 \\
\hline Emotional engagement & 3.20 & 0.818 \\
\hline Behavioural engagement & 2.74 & 0.869 \\
\hline Overall customer engagement & 3.15 & 0.665 \\
\hline
\end{tabular}

$N-196$

Speaking about customer engagement we see that overall customer engagement is moderate ( 3.15 on 5 points scale). The highest being cognitive engagement (3.49) and the lowest - behavioural (2.74). In summary, the findings indicate that respondents are quite passive in their interaction with the object of engagement.

Correlation analysis was performed in order to establish the relations between customer engagement drivers and the engagement with mobile apps. Spearman correlation coefficient was calculated as the KolmogorovSmirnov test showed that distribution was not normal. Results of correlation analysis are presented in Table 3 below. 
Table 3 similarly to the relation between technical convenience and

Correlation between drivers and customer engagement with mobile apps

\begin{tabular}{|l|c|c|c|c|}
\cline { 2 - 5 } \multicolumn{1}{c|}{} & $\begin{array}{c}\text { Behavioural } \\
\text { engage- } \\
\text { ment }\end{array}$ & $\begin{array}{c}\text { Emotional } \\
\text { engage- } \\
\text { ment }\end{array}$ & $\begin{array}{c}\text { Cognitive } \\
\text { engage- } \\
\text { ment }\end{array}$ & $\begin{array}{c}\text { Overall } \\
\text { engage- } \\
\text { ment }\end{array}$ \\
\hline Hedonism & $0.191 * *$ & $0.250^{* *}$ & $0.255^{* *}$ & $0.266^{* *}$ \\
\hline $\begin{array}{l}\text { Customer } \\
\text { sociability }\end{array}$ & $0.349 * *$ & $0.430^{* *}$ & $0.257 * *$ & $0.418^{* *}$ \\
\hline $\begin{array}{l}\text { Technical } \\
\text { convenience }\end{array}$ & $0.353^{* *}$ & $0.484 * *$ & $0.332 * *$ & $0.480^{* *}$ \\
\hline Satisfaction & 0.125 & $0.162 *$ & $0.239 * *$ & $0.204 * *$ \\
\hline
\end{tabular}

Notes: $* *_{-} p<0.001, *-p<0.05$ Spearman's rho correlation coefficient. $N-196$.

Correlation between factors and overall customer engagement showed weak to moderate positive significant relation. The strongest though moderate relation was established between technical convenience and overall engagement ( $r=0.480, p<0.001)$, and between sociability and overall engagement $(r=0.418, p<0.001)$. Hedonism as well as satisfaction had significant positive but weak relation with overall customer engagement ( $r=0.266, p$ $<0.001$ and $r=0.204, p<0.001$, respectively).

When analysing customer engagement through different dimensions it becomes obvious that such factor as hedonism has positive but weak relation with each of three engagement dimensions; the relatively strongest relation is with cognitive engagement $(r=0.255, p<0.001)$ and the weakest with behavioural $(r=0.191, p<0.001)$. Customer sociability has the strongest, although moderate, positive relation with emotional engagement $(r=0.430, p<0.001)$, emotional engagement $(r=0.484, p<0.001)$. Meanwhile satisfaction with apps does not have a significant relation with behavioural engagement at all ( $r=0.125$, n.s.), and the relation with other engagement dimensions is weak.

As correlation confirmed the positive relation (although not so strong) between the factors influencing customer engagement into mobile applications and the customer engagement, the regression analysis was performed to test if those factors significantly predicted consumer engagement. Several different multiply linear regression models were used. At first, in order to test the impact of different factors on overall customer engagement, multiply regression was performed taking separate factors as independent variables and overall customer engagement as dependent variable. Using the enter method it was found that factors explained $41.5 \%$ of variance in overall customer engagement with apps $\left(\mathrm{R}^{2 a d j}=\right.$ $0.415, \mathrm{~F}(4,191)=35.513, p<0.001)$. However, analysis of regression coefficients showed that only two out of four factors significantly predicted the value of customer engagement, namely, customer sociability $(\beta=0.384, p<$ $0.001)$ and technical convenience $(\beta=0.359, p<0.001)$. Hedonism $(\beta=-0.021, p=$ n.s. $)$ and satisfaction with apps $(\beta=0.096, p=$ n.s. $)$ did not have significant impact on customer engagement.

Due to the fact that customer engagement with mobile apps was conceptualized as consisting of three dimensions, the impact of different factors on cognitive, emotional and behavioural engagement was explored. Three more models of multiply regression were developed with each of customer engagement dimension as the dependent variable. The results of regression analysis are provided in Table 4.

Table 4

The results of multiply regression with dimensions of customer engagement as dependent variables

\begin{tabular}{|c|c|c|c|c|c|c|c|}
\hline \multirow{2}{*}{ Model } & \multirow{2}{*}{$\begin{array}{l}\text { Dependent } \\
\text { variable }\end{array}$} & \multirow{2}{*}{$\begin{array}{l}\text { Adjusted } \\
\text { R square }\end{array}$} & \multicolumn{2}{|c|}{ ANOVA } & \multirow{2}{*}{ Predictors } & \multirow{2}{*}{ Beta } & \multirow{2}{*}{ Sig. } \\
\hline & & & $F(\mathbf{d f})$ & Sig. & & & \\
\hline 1 & $\begin{array}{l}\text { Cognitive } \\
\text { engagement }\end{array}$ & 0.145 & $\begin{array}{c}9.299 \\
(4,191)\end{array}$ & 0.000 & $\begin{array}{l}\text { Customer sociability } \\
\text { Technical convenience } \\
\text { Satisfaction } \\
\text { Hedonism }\end{array}$ & $\begin{array}{l}0.181 \\
0.223 \\
0.137 \\
0.008\end{array}$ & $\begin{array}{l}0.015 \\
0.006 \\
0.060 \\
0.993\end{array}$ \\
\hline 2 & $\begin{array}{l}\text { Emotional } \\
\text { engagement }\end{array}$ & 0.365 & $\begin{array}{c}29.040 \\
(4,191)\end{array}$ & 0.000 & $\begin{array}{l}\text { Customer sociability } \\
\text { Technical convenience } \\
\text { Satisfaction } \\
\text { Hedonism }\end{array}$ & $\begin{array}{c}0.351 \\
0.377 \\
0.035 \\
-0.033\end{array}$ & $\begin{array}{l}0.000 \\
0.000 \\
0.569 \\
0.616\end{array}$ \\
\hline 3 & $\begin{array}{l}\text { Behavioural } \\
\text { engagement }\end{array}$ & 0.276 & $\begin{array}{c}19.567 \\
(4,191)\end{array}$ & 0.000 & $\begin{array}{l}\text { Customer sociability } \\
\text { Technical convenience } \\
\text { Satisfaction } \\
\text { Hedonism }\end{array}$ & $\begin{array}{c}0.372 \\
0.249 \\
0.053 \\
-0.018\end{array}$ & $\begin{array}{l}0.000 \\
0.001 \\
0.427 \\
0.800\end{array}$ \\
\hline
\end{tabular}

The results showed that in case of cognitive engagement as dependent variable, four distinguished factors explained only $14.5 \%$ of the variance $\left(\mathrm{R}^{2 a d j}=\right.$ 0.145). As the explaining power was too small, the model did not actually fit the prediction. Anyway, the exploration of standardized beta coefficients showed that only customer sociability and technical convenience factors had the significant impact on cognitive engagement. Similar results were found when analysing other two models of multiply regression with emotional and behavioural engagement as dependent variables. In case of emotional engagement as a dependent variable, the regression model fitted the prediction as it explained $36.5 \%$ of variance in emotional engagement. The strongest impact on emotional engagement had the factor of technical convenience $(\beta=$ $0.377, p<0.001)$ and the impact of customer sociability 
was quite similar $(\beta=0.351, p<0.001)$. Other two factors did not have the significant influence on emotional customer engagement. The third model, with behavioural engagement as a dependent variable, explained $27.6 \%$ of variance. In this case the customer sociability has the strongest positive influence $(\beta=0.372, p<0.001)$, followed by technical convenience $(\beta=0.249, p<0.001)$. Satisfaction with apps and hedonism did not have a significant influence on behavioural engagement, as it didn't in other two cases. It is interesting to notice that the impact of hedonism, although insignificant, was negative in case of emotional and behavioural engagement. Those findings raise considerations about how really hedonism and satisfaction (both concepts being similar in meaning, concerning activities that bring pleasure and selfsatisfaction) relate to consumer engagement.

The portrait of a mobile apps users, identified in this research, suggested young consumers (younger than 25 years old) were the main users of mobile applications. Therefore we decided to apply multiply regression models just for two age groups: 1) younger than 18 years old, and 2) 19-24 years old, to check if there is any kind of different patterns in those two age groups in comparison to the whole sample. The results of regression analysis are provided in Table 5.

Table 5

The results of multiply regression with overall customer engagement as dependent variables in two age groups

\begin{tabular}{|c|c|c|c|c|c|c|c|}
\hline \multirow{2}{*}{ Model } & \multirow{2}{*}{$\begin{array}{c}\text { Dependent } \\
\text { variable }\end{array}$} & \multirow{2}{*}{$\begin{array}{l}\text { Adjusted } \\
\text { R square }\end{array}$} & \multicolumn{2}{|c|}{ ANOVA } & \multirow{2}{*}{ Predictors } & \multirow{2}{*}{ Beta } & \multirow{2}{*}{ Sig. } \\
\hline & & & $F(\mathbf{d f})$ & Sig. & & & \\
\hline $\begin{array}{c}1 \\
\text { Age group: } \\
\text { younger than } \\
18 \text { years old }\end{array}$ & $\begin{array}{l}\text { Overall } \\
\text { engagement }\end{array}$ & 0.517 & $\begin{array}{l}14.388 \\
(4,46)\end{array}$ & 0.000 & $\begin{array}{l}\text { Customer sociability } \\
\text { Technical convenience } \\
\text { Satisfaction } \\
\text { Hedonism }\end{array}$ & $\begin{array}{l}\mathbf{0 . 5 1 0} \\
0.193 \\
0.160 \\
0.031\end{array}$ & $\begin{array}{l}\mathbf{0 . 0 0 0} \\
0.146 \\
0.183 \\
0.793\end{array}$ \\
\hline $\begin{array}{c}\mathbf{2} \\
\text { Age group: } \\
\begin{array}{c}19-24 \text { years } \\
\text { old }\end{array}\end{array}$ & $\begin{array}{l}\text { Overall } \\
\text { engagement }\end{array}$ & 0.398 & $\begin{array}{l}17.054 \\
(4,93)\end{array}$ & 0.000 & $\begin{array}{l}\text { Customer sociability } \\
\text { Technical convenience } \\
\text { Satisfaction } \\
\text { Hedonism }\end{array}$ & $\begin{array}{l}\mathbf{0 . 3 5 9} \\
\mathbf{0 . 3 6 9} \\
0.127 \\
0.072\end{array}$ & $\begin{array}{l}\mathbf{0 . 0 0 0} \\
\mathbf{0 . 0 0 0} \\
0.119 \\
0.435\end{array}$ \\
\hline
\end{tabular}

The regression model in the youngest age group (under 18 years old) showed somewhat strongest explaining power. It was found that factors explained almost $52 \%$ of variance in overall customer engagement with apps $\left(\mathrm{R}^{2 a d j}=\right.$ $0.517, \mathrm{~F}(4,46)=14.388, p<0.001)$. Alas, this explaining power relied only on customer sociability, as this was the only factor with significant positive impact $(\beta=0.212, p<$ $0.001)$. It seems that possibility to socialize with friends and other people through applications is the most important driver for engagement for teenagers.

The regression model in age group of 19-24 years explained almost $40 \%$ of variance in overall engagement. Two out of four predictors, customer sociability and technical convenience had significant positive impact on customer engagement. Those findings suggest the assumption that other things become important with age, as technical convenience along with socialization drive engagement in the group of young adults. However, both regression models corresponded to the previous results in total sample, rejecting the impact of hedonism and satisfaction on customer engagement in mobile applications.

\section{Conclusions}

Abundance of existing studies on customer engagement confirms the importance of the topic and the need for further exploration and thorough investigation of it in different business fields. The ongoing discussion about the phenomenon suggests that ability to engage customers depends on the object of engagement, the participant/subject of engagement and the context of engagement.
With this paper we explored the factors that drive customer engagement into mobile applications. After the literature review, four groups of factors were identified and tested in our empirical study, namely, factors reflecting technical convenience, hedonism, customer sociability and customer satisfaction, which presumably drive the customer engagement in mobile apps. On one hand, the empirical findings showed that neither hedonism experienced when using mobile applications nor the overall satisfaction had a significant impact on customer engagement in mobile applications. On the other hand, the results showed that both hedonism and satisfaction with mobile apps had the highest mean ratings. So, the customers feel satisfaction and hedonism in using mobile apps, but those two factors are not really the drivers for engagement.

Customer engagement has been acknowledged as having a crucial impact on the success in mobile apps market. However, the results of this study showed only moderate overall customer engagement with mobile apps. Customer sociability and technical convenience had been determined as being the only drivers for customer engagement.

After analysis of the impact of different factors on three separate dimensions of the engagement, the importance of sociability and technical convenience on behavioural and emotional engagement were confirmed. However, in case of cognitive engagement as dependent variable, the regression model did not actually fit the prediction, as distinguished factors explained only $14.5 \%$ of the variance. 
Assuming that younger customers may demonstrate different engagement behaviour in mobile applications, the analysis of two younger groups of respondents (those younger than 18 years old and 19-24 years old) was performed. The findings confirmed that technical convenience and sociability are the most important factors when trying to engage young adults in mobile apps. However, hedonism and satisfaction are insignificant. Such findings contradict the research stating that hedonic factors can contribute themselves to the strength of customer engagement (Ho \& Syu, 2010; Higgins \& Scholer, 2009), and customer satisfaction could be treated as the antecedent of engagement (Kim et al., 2013a). Moreover, in the youngest group of respondents (younger than 18) the sociability was the only factor contributing to their engagement in the mobile applications. Therefore, the practical implications for app developers is to take into account that an app should have the ability to share, communicate, comment, meet others with similar interests to increase customer engagement with that app. Acknowledging the fact that the youngest group of respondents represents the future customers of smartphones, these circumstances should be taken into account then developing apps and creating social interactive platforms for mobile devices.

When developing apps for young adults, the importance of the technical convenience (i.e. the novelty, the explicit and understandable profile, ability to improve life quality, etc.) also should not be neglected by app developers, as it has been determined to be the second important factor of customer engagement in mobile applications.

In order to further explore customer engagement factors, additional thorough studies are necessary to find out what constitutes hedonism and overall satisfaction for different customers in particular context.

\section{References}

Banyte, J., Tarute, A., \& Taujanskyte, I. (2014). Customer Engagement into Value Creation: Determining Factors and Relations with Loyalty. Inzinerine Ekonomika-Engineering Economics, 25(5), 568-577. http://dx.doi.org/10.5755/j01.ee.25.5.8402

Bellman, S., Potter, R. F., Treleaven-Hassard, S., Robinson, J. A., \& Varan, D. (2011). The effectiveness of branded mobile phone apps. Journal of Interactive Marketing, 25(4), 191-200. http://dx.doi.org/10.1016/j.intmar.2011.06.001

Breidbach, F. C., Brodie, R., \& Hollebeek, L. (2014). Beyond virtuality: from engagement platforms to engagement ecosystems. Managing Service Quality, 24(6), 592-611. http://dx.doi.org/10.1108/MSQ-08-2013-0158

Brodie, R. J., Hollebeek, L. D., Juric, B., \& Ilic, A. (2011). Customer engagement: conceptual domain, fundamental propositions, and implications for research. Journal of Service Research, 1094670511411703.

Brodie, R. J., Ilic, A., Juric, B., \& Hollebeek, L. (2013). Consumer engagement in a virtual brand community: An exploratory analysis. Journal of Business Research, 66(1), 105-114. http://dx.doi.org/10.1016/j.jbusres.2011.07.029

Cheung, C., Lee, M., \& Jin, X. (2011). Customer engagement in an online social platform: A conceptual model and scale development. ICIS 2011 Proceedings, 1-8.

Dessart, L., Veloutsou, C., \& Morgan-Thomas, A. (2016). Capturing consumer engagement: duality, dimensionality and measurement. Journal of Marketing Management, 32, 399-426. http://dx.doi.org/10.1080/0267257X.2015.1130738

Dovaliene, A., Masiulyte, A., \& Piligrimiene, Z. (2015). The Relations between Customer Engagement, Perceived Value and Satisfaction: The Case of Mobile Applications. Procedia-Social and Behavioral Sciences, 213, $659-664$. http://dx.doi.org/10.1016/j.sbspro.2015.11.469

Euromonitor International (2016). Accessed 15 February 2016: https://www.portal.euromonitor.com/portal/statistics/tab

Fernandes, T., \& Remelhe, P. (2015). How to engage customers in co-creation: customers' motivations for collaborative innovation. Journal of Strategic Marketing, 1-16. http://dx.doi.org/10.1080/0965254X.2015.1095220

Gambetti, R. C., \& Graffigna, G. (2010). The concept of engagement: A systematic analysis of the ongoing marketing debate. International Journal of Market Research, 52, 801-826. http://dx.doi.org/10.2501/S147078531020166

Higgins, E. T., \& Scholer, A. A. (2009). Engaging the consumer: The science and art of the value creation process. Journal of Consumer Psychology, 19(2), 100-114 http://dx.doi.org/10.1016/j.jcps.2009.02.002

Ho, H. Y., \& Syu, L. Y. (2010, August). Uses and gratifications of mobile application users. In Electronics and Information Engineering (ICEIE), 2010 International Conference On Electronics and Information Engineering, Kyoto, Japan (Vol. 1, pp. V1-315). IEEE. http://dx.doi.org/10.1109/ICEIE.2010.5559869

Hollebeek, L. D. (2013). The customer engagement/value interface: An exploratory investigation. Australasian Marketing Journal (AMJ), 21(1), 17-24. http://dx.doi.org/10.1016/j.ausmj.2012.08.006

Hollebeek, L. D., Glynn, M. S., \& Brodie, R. J. (2014). Consumer brand engagement in social media: Conceptualization, scale development and validation. Journal of Interactive Marketing, 28(2),149-165. http://dx.doi.org/10.1016 j.intmar.2013.12.002

Jones, M. A., \& Suh, J. (2000). Transaction-specific satisfaction and overall satisfaction: an empirical analysis. Journal of Services Marketing, 14(2), 147-159. http://dx.doi.org/10.1108/08876040010371555 
Kim, Y. H., Kim, D. J., \& Wachter, K. (2013a). A study of mobile user engagement (MoEN): Engagement motivations, perceived value, satisfaction, and continued engagement intention. Decision Support Systems, 56, 361-370. http://dx.doi.org/10.1016/j.dss.2013.07.002

Kim, E., Lin, J. S., \& Sung, Y. (2013b). To app or not to app: Engaging consumers via branded mobile apps. Journal of Interactive Advertising, 13(1), 53-65. http://dx.doi.org/10.1080/15252019.2013.782780

Kim, S. J., Wang, R. J. H., \& Malthouse, E. C. (2015). The Effects of Adopting and Using a Brand's Mobile Application on Customers' Subsequent Purchase Behavior. Journal of Interactive Marketing, 31, 28-41. http://dx.doi.org/10.1016/j. intmar.2015.05.004

Krishna, A., Lazarus, D., \& Dhaka, S. (2013). Co-creation channel: A concept for paradigm shift in value creation. Journal of Management Science and Practice, 1(1), 14-21.

Kumar, V., Aksoy, L., Donkers, B., Venkatesan, R., Wiesel, T., \& Tillmanns, S. (2010). Undervalued or overvalued customers: capturing total customer engagement value. Journal of Service Research, 13(3), 297-310. http://dx.doi.org/10. $1177 / 1094670510375602$

Leckie, C., Nyadzayo, M. W., \& Johnson, L. W. (2016). Antecedents of consumer brand engagement and brand loyalty. Journal of Marketing Management, 1-21. http://dx.doi.org/10.1080/0267257x.2015.1131735

Lim, S. L., Bentley, P. J., Kanakam, N., Ishikawa, F., \& Honiden, S. (2015). Investigating country differences in mobile app user behavior and challenges for software engineering, IEEE Transactions on Software Engineering, 41(1), 40-64. http://dx.doi.org/10.1109/TSE.2014.2360674

Macey, W. H. \& Schneider, B. (2008). The Meaning of Employee Engagement, Industrial and Organizational Psychology, 1 (1), 3-30. http://dx.doi.org/10.1111/j.1754-9434.2007.0002.x

Maslowska, E., Malthouse, E. C., \& Collinger, T. (2016). The customer engagement ecosystem. Journal of Marketing Management, 32:5-6, 469-501. http://dx.doi.org/10.1080/0267257X.2015.1134628

Mollen, A., \& Wilson, H. (2010). Engagement, telepresence and interactivity in online consumer experience: Reconciling scholastic and managerial perspectives. Journal of Business Research, 63(9), 919-925. http://dx.doi.org/10.1016/ j.jbusres.2009.05.014

MSI (2015a) Marketing Science Institute (interactive). Accessed 16 December 2015: http://www.msi.org/research/2014-2016research-priorities/tier-1-understanding-customers-and-the-customer-experience/

MSI (2015b) Marketing Science Institute (interactive). Accessed 16 December 2015: http://www.msi.org/research/2014-2016research-priorities/tier-2-leveraging-digital-social-mobile-technology/

Sashi, C. M. (2012). Customer engagement, buyer-seller relationships, and social media. Management decision, 50(2), $253-272$. http://dx.doi.org/10.1108/00251741211203551

Spiteri, J. M., \& Dion, P. A. (2004). Customer value, overall satisfaction, end-user loyalty, and market performance in detail intensive industries. Industrial Marketing Management, 33(8), 675-687. http://dx.doi.org/10.1016/j.indmarman. 2004.03.005

Sterling, G. (2014). Report: Mobile Users Spend 80 Percent Of Time In Just Five Apps. (Interactive). Accessed 26 April 2015 : http://marketingland.com/report-mobile-users-spend-80-percent-time-just-five-apps-116858

Van Doorn, J., Lemon, K. N., Mittal, V., Nass, S., Pick, D., Pirner, P., \& Verhoef, P. C. (2010). Customer engagement behavior: Theoretical foundations and research directions. Journal of Service Research, 13(3), $253-266$. http://dx.doi.org/10.1177/1094670510375599

Vivek, S. D., Beatty, S. E., \& Morgan, R. M. (2012). Customer engagement: Exploring customer relationships beyond purchase. The Journal of Marketing Theory and Practice, 20(2), p. 122-146. http://dx.doi.org/10.2753/MTP1069-6679200201

Zhang, H., Lu, Y., Gupta, S., \& Zhao, L. (2014). What motivates customers to participate in social commerce? The impact of technological environments and virtual customer experiences. Information \& Management, 51(8), 1017-1030. http://dx.doi.org/10.1016/j.im.2014.07.005

Zhao, Z., \& Balague, C. (2015). Designing branded mobile apps: Fundamentals and recommendations. Business Horizons, 58(3), 305-315. http://dx.doi.org/10.1016/j.bushor.2015.01.004

The article has been reviewed. Received in January, 2016; accepted in April, 2016. 